\title{
CAN WE DISPENSE WITH THE ARTS?
}

\author{
Emmanuel Ifeanyi Ani* \\ DOI: http://dx.doi.org/10.4314/ujah.v12i2.2
}

\section{Abstract}

From the inception of the European renaissance and the age of Enlightenment which gave science the ground to blossom and test its methods of inquiry, and science subsequently achieved such monumental success as to transform the society into a place of so much comfort and efficiency, the significance of the arts has contended with the prospect of relegation. The lack of glaring physical products from theorization reminiscent of science has earned art a skeptical and disdainful attitude from people. A philosophical analysis of this issue, however, reveals that this presumptive disdain of the arts is gravely mistaken. Hermeneutical investigation of human existence, for instance, reveals that scientific hypothesizing, which precedes scientific experimentation and invention, must begin with the process of imagination in terms of the picturing of hypothetical reality, which belongs, not to science, but to art, making art a precedent as well as a condition for scientific knowledge.

\section{The Meaning of Art}

Traditionally, the term art was used to refer to any skill or mastery. This conception changed during the Romantic period, when art came to be seen as "a special faculty of the human mind to be classified with religion and science." ${ }^{1}$ Generally, art is made with the intention of stimulating thoughts and emotions. The Encyclopedia Britannica defines art as "the use of skill and imagination in the creation of aesthetic objects, environments, or experiences that can be shared with others." ${ }^{2}$ By this definition of the word, artistic 
works have existed for almost as long as humankind: from early pre-historic art to contemporary art, even though some befuddled theories tried to restrict the concept to modern Western societies. ${ }^{3}$

Referring to the difficulty of defining art, Richard Wollheim described art as "one of the most elusive of the traditional problems of human culture." ${ }^{4}$ It has been defined as a vehicle for the expression or communication of emotions and ideas. Leo Tolstoy identified art as a use of indirect means to communicate from one person to another. ${ }^{5}$ Benedetto Croce and R.G. Collingwood are of the view that art expresses emotions, and that the work of art therefore essentially exists in the mind of the creator. ${ }^{6}$ The above views of arts are lopsided to fine art and music because art in its entire scope and classifications, as we shall shortly see, is not restricted to exciting the emotions or indirect communication. Indeed, philosophy, which is classified as art, is basically a preserve of reason, and has little to do with emotions and feelings, and its communication is more or less direct, objective and clear. More specifically, the activity of speculation and reasoning on first principles, which is the usual engagement of philosophy, is likely to involve a restriction on the emotions or their relegation to a position of less significance. Martin Heidegger has influenced the view of art as the means by which a community develops for itself a medium for self-expression and interpretation. ${ }^{7}$

Art can be seen the process or product of deliberately arranging elements in a way to inform the intellect, or/and affect the senses or emotions. It is basically a work of skill and imagination. We can talk about two main divisions of art: fine or plastic art such as paintings, drawings, sculpture; performance arts such as music; and verbal art which we know as literature. Literature here includes linguistics, prose, poetry and philosophy. Therefore, our discussions of art and 
its role in society will take account of these three aspects of art. This means that our discussion will encompass the history, development, role and relevance of the written arts, fine arts, theater and musical arts. Art in its strictest sense encompasses these fields. A closer look at these fields will reveal that they have a common denominator, which is that they are concerned with imparting one value or another to the individual and society.

\section{Development of Arts in History}

A brief excursion of the historical development of the various arts will enlighten us more on its place, role and importance in society and begin to clarify the reader even before our evaluation on whether indeed art can be dispensed with:

\section{Fine Art}

Civilization in evolution has often been equated with the advancement of its arts. According to Tim Radford, the oldest art objects in the world, which were a series of tiny, drilled snail shells about 75,000 years old, were discovered in a South African cave. ${ }^{8}$ Many of the world's ancient civilizations such as Ancient Egypt, Mesopotamia, Persia, India, China, Ancient Greece, Rome, as well as Inca, Maya, and Olmec, have produced great works of art. Each of these centers of early civilization developed a unique style in their art.

During the Middle Ages, Western art focused on the expression of Biblical and not material truths, and used styles that showed the higher unseen glory of a heavenly world, such as the use of gold in the background of paintings, or glass in mosaics or windows, which also presented figures in idealized, patterned or flat forms. ${ }^{9}$ Renaissance art tried to be more realistic in depicting the material world, and the place of humans in it. In the east, religion dominated artistic styles 
and forms. In the twentieth century art began to search for new standards, and so it passed through stages like Impressionism and Expressionism. ${ }^{10}$ Due to globalization, art from other cultures began to influence Western art, like African sculpture influencing the Pablo Picasso. Moreover, modernism which involved the search for truth soon gave way to post modernism which involves the view that truth is unattainable, and this gave way to contemporary art which projects relativism. ${ }^{11}$ This type of art shows different cultures and histories of the world as changing. Others factors that brought this about are the new discoveries of relativity by Einstein and psychoanalysis by Sigmund Freud, and also by unprecedented technological development which was accelerated in two world wars.

\section{Music}

Prehistoric music is summarized as stemming from naturally occurring sounds and rhythms, which may have served entertainment (game) or practical (luring animals in hunt) functions. It is possible that the first musical instrument was the human voice itself, which can make a vast array of sounds, from singing, humming and whistling through to clicking, coughing and yawning. In 2008 archaeologists discovered a bone flute in the Hohle Fels cave near Ulm, Germany. ${ }^{12}$ The five-holed flute has a V-shaped mouthpiece and is made from a vulture wing bone. The oldest known wooden pipes were discovered near Greystones, Ireland, in 2004.

According to Easton's Bible Dictionary, Jubal was the inventor of musical instruments. ${ }^{13}$ The Hebrews were much given to the cultivation of music, beginning with the first mention of music is in the account of Laban's interview with $\mathrm{Jacob}^{14}$, the song of deliverance after crossing the red sea ${ }^{15}$, the period of Samuel ${ }^{16}$, Solomon's Temple. ${ }^{17}$ In private life 
also music seems to have held an important place among the Hebrews. ${ }^{18}$ Music scholars identified common links between musical activity of the Hebrews with those of the later cultures of the Greeks and Romans. The common area of performance is a "social phenomenon called litany," a form of prayer consisting of a series of invocations or supplications. The Journal of Religion and Theatre notes that among the earliest forms of litany, "Hebrew litany was accompanied by a rich musical tradition:"19 ${ }^{19}$ The prophet Samuel was the patriarch of a school which taught not only prophets and holy men, but also sacred-rite musicians. This public music school, perhaps the earliest in recorded history, was not restricted to a priestly class--which is how the shepherd boy David appears on the scene as a minstrel to King Saul. ${ }^{20}$

The prehistoric era is considered to have ended with the development of writing, and with it, by definition, prehistoric music. "Ancient music" is the name given to the music that followed. The "oldest known song" was written in cuneiform, dating to 4,000 years ago from Ur. It was deciphered by Prof. Anne Draffkorn Kilmer (University of California at Berkeley), and was demonstrated to be composed in harmonies of thirds, like ancient gymel, ${ }^{21}$ and also was written using a Pythagorean tuning of the diatonic scale. Aristotle in his Problems described musical techniques of the time, like polyphony, common with the ancient Greeks. ${ }^{22}$ Here, one pipe in the aulos pairs (double flutes) likely served as a drone or "keynote," while the other played melodic passages. Instruments, such as the seven holed flute and various types of stringed instruments have been recovered from the Indus valley civilization archaeological sites. $^{23}$

Indian classical music (marga) can be found from the scriptures of the Hindu tradition, the Vedas. Samaveda, one 
of the four vedas, describes music at length. The history of musical development in Iran (Persian music) dates back to the prehistoric era. The great legendary king, Jamshid, is credited with the invention of music. Music in Iran can be traced back to the days of the Elamite Empire (2,500-644 B.C). Fragmentary documents from various periods of the country's history establish that the ancient Persians possessed an elaborate musical culture. The Sassanid period (A.D. 226651), in particular, has left us ample evidence pointing to the existence of a lively musical life in Persia. The names of some important musicians such as Barbod, Nakissa and Ramtin, and titles of some of their works have survived. ${ }^{24}$

Baroque music, which covered the period from the fall of the Roman Empire, in $476 \mathrm{CE}$, until the middle of the 18th century, was extremely diverse, encompassing multiple cultural traditions within a wide geographic area. What unified these cultures in the Middle Ages was the Roman Catholic Church, and its music served as the focal point for musical development for the first thousand years of this period. While musical life was undoubtedly rich in the early Medieval era, as attested by artistic depictions of instruments, writings about music, and other records, the only repertory of music which has survived from before 800 to the present day is the plainsong liturgical music of the Roman Catholic Church, the largest part of which is called Gregorian chant. Pope Gregory I, who gave his name to the musical repertory and may himself have been a composer, is usually claimed to be the originator of the musical portion of the liturgy in its present form, though the sources giving details on his contribution date from more than a hundred years after his death. ${ }^{25}$

Renaissance in music began when, by the middle of the 15th century, composers and singers from the Low Countries and adjacent areas began to spread across Europe, 
especially into Italy, where they were employed by the papal chapel and the aristocratic patrons of the arts (such as the Medici, the Este, and the Sforza families). ${ }^{26}$ They carried their style with them: smooth polyphony which could be adapted for sacred or secular use as appropriate.

The invention of printing had an immense influence on the dissemination of musical styles, and along with the movement of the Franco-Flemish musicians, contributed to the establishment of the first truly international style in European music since the unification of Gregorian chant under Charlemagne. But by the middle of the 16th century, the international style began to break down, and several highly diverse stylistic trends became evident: a trend towards simplicity in sacred music. ${ }^{27}$ Instrumental music became dominant in the Baroque, and most major music forms were defined. Much Baroque music featured a basso continuo consisting of a keyboard, either harpsichord or organ (sometimes a lute instead), and a bass instrument, such as a viola da gamba or bassoon. The three outstanding composers of the period were Johann Sebastian Bach, George Frideric Handel, and Antonio Vivaldi, but a host of other composers, some with huge output, were active in the period. $^{28}$

The early Classical period was ushered in by the Mannheim School, which included such composers as Johann Stamitz, Franz Xaver Richter, Carl Stamitz, and Christian Cannabich. It exerted a profound influence on Joseph Haydn and, through him, on all subsequent European music. Wolfgang Amadeus Mozart was the central figure of the Classical period, and his phenomenal and varied output in all genres defines our perception of the period. Ludwig van Beethoven and Franz Schubert were transitional composers, leading into the Romantic period, with their expansion of existing genres, forms, and even functions of music. ${ }^{29}$ In the 
Romantic period, music became more expressive and emotional, expanding to encompass literature, art, and philosophy. The late 19th century saw a dramatic expansion in the size of the orchestra and in the role of concerts as part of urban society, prominently featuring Johann Strauss II, Brahms, Liszt, Tchaikovsky, Verdi, and Wagner. A prominent mark of late 19th century music is its nationalistic fervor, as exemplified by such figures as Dvořák, Sibelius, and Grieg. ${ }^{30}$

The 20th Century saw a revolution in music listening as the radio gained popularity worldwide and new media and technologies were developed to record, capture, reproduce and distribute music. Because music was no longer limited to concerts and clubs, it became possible for music artists to quickly gain fame nationwide and sometimes worldwide. Conversely, audiences were able to be exposed to a wider range of music than ever before. Music performances became increasingly visual with the broadcast and recording of music videos and concerts. Music of all kinds also became increasingly portable. Headphones allowed people sitting next to each other to listen to entirely different performances or share the same performance. 20th Century music brought a new freedom and wide experimentation with new musical styles and forms that challenged the accepted rules of music of earlier periods. The invention of musical amplification and electronic instruments, especially the synthesizer, in the mid20th century revolutionized popular music and accelerated the development of new forms of music. ${ }^{31}$

\section{Literature (Prose, Poetry, Linguistics and Philosophy)}

The determination of the origin of literature is qualified by the fact that not all writings can be called literature. When we understand literature for instance as "... writings in prose or poetry which attempt to provide entertainment, 
enlightenment, or instruction to the reader/hearer/observer, as well as the development of the literary techniques used in the communication of these pieces" 32 , then it is difficult to see how data books, registers and log books can fit in. On this account, the very first writings from ancient Sumer by any reasonable definition do not constitute literature - the same is true of some of the early Egyptian hieroglyphics or the thousands of logs from ancient Chinese regimes.

We may, however, consider certain texts as literature's first stirrings. Very early examples are Epic of Gilgamesh, in its Sumerian version predating 2000 BC, and the Egyptian Book of the Dead written down in the Papyrus of $A n i$ in approximately $250 \mathrm{BC}$ but probably dates from about the 18th century BC. Many texts handed down by oral tradition over several centuries before they were fixed in written form are difficult or impossible to date. The core of the Rigveda may date to the mid 2nd millennium BC. The Pentateuch is traditionally dated to the 15 th century, although modern scholarship estimates its oldest part to date to the 10th century BC at the earliest. Homer's Iliad and Odyssey date to the 8th century $\mathrm{BC}$ and mark the beginning of Classical Antiquity. Notable among later Greek poets was Sappho, who defined, in many ways, lyric poetry as a genre. Indian śruti texts post-dating the Rigveda (such as the Yajurveda, the Atharvaveda and the Brahmanas), as well as the Hebrew Tanakh and the mystical collection of poems attributed to Lao Tze, the Tao te Ching, date to the Iron Age, but their dating is difficult and controversial. The great Hindu epics were also transmitted orally, likely predating the Maurya period. Other oral traditions were fixed in writing much later, such as the Elder Edda, written down in the 12th or 13 th century. 33

Many authors consider the western literary tradition to have begun with the epic poems The Iliad and The Odyssey, 
which remain giants in the literary canon for their skillful and vivid depictions of war and peace, honor and disgrace, love and hatred. A playwright named Aeschylus changed Western literature forever when he introduced the ideas of dialogue and interacting characters to playwriting. In doing so, he essentially invented "drama": his Oresteia trilogy of plays is seen as his crowning achievement. Other refiners of playwriting were Sophocles and Euripides. Sophocles is credited with skillfully developing irony as a literary technique, most famously in his play Oedipus the King. Euripedes, conversely, used plays to challenge societal norms and mores - a hallmark of much of Western literature for the next 2,300 years and beyond-and his works such as Medea, The Bacchae and The Trojan Women are still notable for their ability to challenge our perceptions of propriety, gender, and war. Aristophanes, a comic playwright, defines and shapes the idea of comedy almost as Aeschylus had shaped tragedy as an art form-Aristophanes' most famous plays include the Lysistrata and The Frogs.

Philosophy entered literature in the dialogues of Plato, who converted the give and take of Socratic questioning into written form. Aristotle, Plato's student, wrote dozens of works on many scientific disciplines, but his greatest contribution to literature was likely his Poetics, which lays out his understanding of drama, and thereby establishes the first criteria for literary criticism.

The New Testament is an unusual collection of texts-Paul's epistles are the first collection of personal letters to be treated as literature, the Gospels arguably present the first realistic biographies in Western literature, and John's Book of Revelation, though not the first of its kind, essentially defines apocalypse as a literary genre.

Roman Republic writers chose to imitate Greek authors in preference to innovation. Virgil's Aeneid, in many 
respects, emulated Homer's Iliad; Plautus, a comic playwright, followed in the footsteps of Aristophanes; Tacitus' Annals and Germania follow essentially the same historical approaches that Thucydides devised; Ovid and his Metamorphoses explore the same Greek myths again in new ways. Satire is one of the few Roman additions to literatureHorace was the first to use satire extensively as a tool for argument, and Juvenal made it into a weapon.

Augustine of Hippo and his The City of God did for religious literature essentially what Plato had done for philosophy, but Augustine's approach was far less conversational and more didactive. ${ }^{35}$ His Confessions is perhaps the first true autobiography, and it gave rise to the genre of confessional literature which is now more popular than ever. ${ }^{36}$

In-between Rome's fall and the Florentine Renaissance, medieval literature focused more and more on faith and faith-related matters, in part because the works written by the Greeks had not been preserved in Europe, and therefore there were few models of classical literature to learn from and move beyond. Following Rome's fall, Islam's spread across Asia and Africa and brought with it a desire to preserve and build upon the work of the Greeks, especially in literature. Although much had been lost to the ravages of time (and to catastrophe, as in the burning of the Library of Alexandria), many Greek works remained extant: they were preserved and copied carefully by Muslim scribes. In Europe Geoffrey of Monmouth wrote works which he claimed were histories of Britain. These were highly fanciful and included stories of Merlin the magician and King Arthur. Thomas Aquinas, more than any other single person, was able to turn theology into a kind of science, in part because he was heavily influenced by Aristotle, whose works were returning to Europe in the $1200 \mathrm{~s}$. 
The most well known fiction from the Islamic world was The Book of One Thousand and One Nights (Arabian Nights), which was a compilation of many earlier folk tales told by the Persian Queen Scheherazade. A number of stories within the One Thousand and One Nights (Arabian Nights) also feature science fiction elements. One example is "The Adventures of Bulukiya", where the protagonist Bulukiya's quest for the herb of immortality leads him to explore the seas, journey to the Garden of Eden and to Jahannam, and travel across the cosmos to different worlds much larger than his own world, anticipating elements of galactic science fiction. ${ }^{37}$ From Persian culture the book Rubaiyat of Omar Khayyam, written by the Persian mathematician and astronomer Omar Khayyám (1048-1122), became famous in the West. ${ }^{38}$

Some authors feel that China originated the novel form with the Romance of the Three Kingdoms by Luo Guanzhong (in the 14th century), although others feel that this epic is distinct from the novel in key ways. The true vernacular novel was developed in China during the Ming Dynasty (1368-1644 AD). ${ }^{39}$

Classical Japanese literature generally refers to literature produced during the Heian Period, what some would consider a golden era of art and literature. The Tale of Genji (early eleventh century) by Murasaki Shikibu is considered the pre-eminent masterpiece of Heian fiction and an early example of a work of fiction in the form of a novel. It is sometimes called the world's first novel, the first modern novel, the first romance novel, the first psychological novel, or the first novel to still be considered a classic. The 10th century Japanese narrative, The Tale of the Bamboo Cutter, can be considered an early example of proto-science fiction. ${ }^{40}$

The Renaissance brought about the emergence of Johann Gutenberg and his invention of the printing press in 
1455, an innovation (for Europe, at least) that would change literature forever. Texts were no longer precious and expensive to produce - they could be cheaply and rapidly put into the marketplace. Literacy went from the prized possession of the select few to a much broader section of the population (though by no means universal). William Caxton was the first English printer and published English language texts including Le Morte d'Arthur (a collection of oral tales of the Arthurian Knights which is a forerunner of the modern novel) and Geoffrey Chaucer's Canterbury Tales. The form of writing now commonplace across the world - the noveloriginated from the early modern period and grew in popularity in the next century. ${ }^{41}$ Before the modern novel became established as a form there first had to be a transitional stage when "novelty" began to appear in the style of the epic poem.

The early 18th century sees the conclusion of the Baroque period and the incipient Age of Enlightenment with authors such as Immanuel Kant, Voltaire, Jean-Jacques Rousseau or Gotthold Ephraim Lessing. The late 18th century in Germany sees the beginning Romantic (Novalis) and Sturm und Drang (Goethe und Schiller) movements. ${ }^{42}$ In Britain, the 19th century is dominated by the Victorian era, characterized by Romanticism, with Romantic poets such as William Wordsworth, Lord Byron or Samuel Taylor Coleridge and genres such as the gothic novel. In the later 19th century, Romanticism is countered by Realism and Naturalism. The main periods of 20th century literature are captured in the bipartite division, Modernist and Post-modern literature, flowering from roughly 1900 to 1940 and 1945 to 1980 respectively.

Developments in philosophy reflected the literary evolution, just as there were philosophical issues raised by the use of literature. Plato, for instance, believed that literary 
culture and even the lyrics of popular music had a strong impact on the ethical outlook of its consumers. In The Republic, Plato displays a strong hostility to the contents of the literary culture of his period, and proposes a strong censorship of popular literature in his utopia. ${ }^{4}$

More recently, however, philosophers of various stripes have taken different and less hostile approaches to literature. Since the work of the British Empiricists and Immanuel Kant in the late eighteenth century, Western philosophy has been preoccupied with a fundamental question of epistemology: the question of the relationship between ideas in the human mind and the world existing outside the mind, if in fact such a world exists. In more recent years, these epistemological issues have turned instead to an extended discussion of words and meaning: can language in fact bridge the barrier between minds? This cluster of issues concerning the meaning of language and of "writings" sometimes goes by the name of the linguistic turn. ${ }^{44}$

As such, techniques and tools developed for literary criticism and literary theory rose to greater prominence in Western philosophy of the late twentieth century. Philosophers of various stripes paid more attention to literature than their predecessors did. ${ }^{45}$ Some sought to examine the question of whether it was in fact truly possible to communicate using words, whether it was possible for an author's intended meaning to be communicated to a reader. Others sought to use literary works as examples of contemporary culture, and sought to reveal unconscious attitudes they felt present in these works for the The purpose of social criticism. ${ }^{46}$

The bond between philosophy and literature seems to be inseparable: a piece of literature does not seem to have the capacity to capture the audience if its theme has no philosophical significance or 'lessons'; and philosophy can rarely do without literature. A number of poets have written 
poems on philosophical themes, and likewise some important philosophers have expressed their philosophy in verse. The cosmogony of Hesiod and the De Rerum Natura of Lucretius are important philosophical poems. The genre of epic poetry was also used to teach philosophy. Vyasa narrated the ancient Indian epic Mahabharata in order to teach Indian philosophy and Hindu philosophy. Homer also presented some philosophical teachings in his Odyssey. Many of the Eastern philosophers worked out their thought in poetical fashion. Some of the important names include: Vyasa, Jalal ad-Din Muhammad Rumi, Omar Khayyám, Sheikh Saadi, Hafiz Shirazi, Muhammad Iqbal, Matsuo Bashō, Farad ud-Din Attar. Notable Western philosophical poets include: St. John of the Cross, T. S. Eliot, Hildegard von Bingen, Homer, James Wright, Marianne Moore, Pablo Neruda, William Carlos Williams, Mary Oliver, Leslie Marmon Silko, and Robert Creeley. 47

Some philosophers have undertaken to write philosophy in the form of fiction, including novels and short stories. Plato wrote dialogues in which fictional or fictionalized characters discuss philosophical subjects; Socrates frequently appears as a protagonist in Plato's dialogues, and the dialogues are one of the prime sources of knowledge about Socrates' teaching, though it is sometimes hard to distinguish Socrates' actual positions from Plato's own. Numerous early Christian writers, including Augustine, Boethius, and Peter Abelard produced dialogues, just as several early modern philosophers, such as George Berkeley and David Hume.

Other philosophers have resorted to narrative to get their teachings across, like the classical 12th century Islamic philosopher, Abubacer (Ibn Tufail), with his fictional Arabic narrative Philosophus Autodidactus which was written as a response to al-Ghazali's The Incoherence of the Philosophers, 
and then the 13th century Islamic theologian-philosopher Ibn al-Nafis who also wrote a fictional narrative Theologus Autodidactus as a response to Abubacer's Philosophus Autodidactus. ${ }^{48}$ The German philosopher Friedrich Nietzsche often articulated his ideas in literary modes, most notably in Thus Spoke Zarathustra, a re-imagined account of the teachings of Zoroaster. The French existentialist literature which used fiction to convey their authors' philosophical views include Jean-Paul Sartre's novel Nausea and play No Exit, and Albert Camus's The Stranger.

A number of philosophers have had important influence on literature. Arthur Schopenhauer, largely as a result of his system of aesthetics, is perhaps the most influential recent philosopher in the history of literature; Thomas Hardy's later novels frequently allude to Schopenhauerian themes, particularly in Jude the Obscure. Schopenhauer also had an important influence on Joseph Conrad. Schopenhauer also had a less specific but more widely diffused influence on the Symbolist movement in European literature. $^{49}$ Lionel Johnson also refers to Schopenhauer's aesthetics in his essay The Cultured Faun.

Other works of fiction considered to have philosophical content include: Abubacer, Philosophus Autodidactus; Joseph Conrad, Heart of Darkness; Fyodor Dostoevsky, Crime and Punishment; James Joyce, Ulysses; Franz Kafka, The Metamorphosis; Milan Kundera, The Unbearable Lightness of Being; Ibn al-Nafis, Theologus Autodidactus; Thomas Mann, The Magic Mountain; Iris Murdoch, The Sea, the Sea; Marcel Proust, In Search of Lost Time; Tom Robbins, Even Cowgirls Get the Blues; William Shakespeare, Hamlet; Leo Tolstoy, The Death of Ivan Ilyich; Sergio Troncoso, The Nature of Truth; and Robert M. Pirsig, Zen and the Art of Motorcycle Maintenance. ${ }^{50}$ One might add to this list the prominent African narrative which is largely 
philosophical in content: Chinua Achebe's Things Fall Apart. According to Ifechukwu Ndianefoo:

Chinua Achebe's pioneering work, 'Things Fall Apart' appeared at a time cultural chauvinism was instigated and sustained by leading Western scholars to justify colonialism. Africa's rich culture portrayed in the 'Things Fall Apart' stands as a strong antidote to Western cultural chauvinism... moreover, the work shows how Achebe employs his key characters and scenes to portray African philosophy in its sociopolitical, metaphysical, epistemic, aesthetic and ethical aspects. What is more, the work argues that African philosophy portrayed through Achebe's characters and scenes compete most strongly in substance and form with Western philosophy. Indeed, it is argued that, in its specificities, African philosophy in 'Things Fall Apart' has its specific parallels in Western philosophy; for instance, Okonkwo and what he stands for is a quintessential parallel to Nietzsche's philosophy of ubberman (superman). ${ }^{51}$

Ndianefoo concludes that “... the essay urges cultural chauvinists to eschew cultural grandstanding and help create conducive atmosphere for cross-cultural dialogue, understanding and world peace." ${ }^{.52}$

\section{Motivated and Non-motivated Functions of Art}

The classification of the functions of art into the motivated and non-motivated categories derives its basis from the general tendency to view art as non-productive chiefly in the 
material and social senses. Deeper analysis however immediately reveals the dual, or, in common parlance, double role of arts in satiating the human desire for beauty and knowledge and serving some utilitarian purposes. Consider the assertion that: "Art may give insight into the human condition. Art relates to science and religion. Art serves as a tool of education, or indoctrination, or enculturation. Art makes us more moral. It uplifts us spiritually. Art is politics by other means. Art has the value of allowing catharsis." This assertion clearly points to both the materially and socially productive and non-productive value of art. Referring to the non-productive, but no less important in value, Douglas Adams observed that: "It has been said, that a Vogon Starship arriving at the earth and ordering its destruction would ask what use is humanity? The only justification humanity could give would be a Shakespeare play, a Rembrandt or a Bach concerto. These are the things of value which define humanity itself." 54 It follows from this perspective that the non-utilitarian value of art does not subtract from its relevance. This non-utilitarian attributes and non-motivated functions of art stems from the constitution of art as integral to the human being.

\section{Art as Integral to the Human Being (Non-Motivational Functions of Art)}

The non-motivated purposes of art are those that are integral to the being human, transcend the individual or make the individual to transcend mere temporality, or do not fulfill a specific external purpose. In this sense, art, as creativity, is in the very nature of man and can therefore extend beyond mere utility. One aspect of this human attribute is the basic human instinct for harmony, balance, rhythm: Art at this level is not an action or an object, but an internal appreciation of balance and harmony (beauty), and therefore an aspect of being 
human beyond utility. According to Aristotle, "Imitation, then, is one instinct of our nature. Next, there is the instinct for 'harmony' and rhythm, meters being manifestly sections of rhythm. Persons, therefore, starting with this natural gift developed by degrees their special aptitudes, till their rude improvisations gave birth to Poetry." 55 Here we see the transcendal and integral deposit of art in the human being as a human attribute and not as an external art object. This means that art is man per se.

This transcendental dimension to art as a human being helps us to experience the mysterious, in terms of providing a way to experience one's self in relation to the universe. This experience may often come unmotivated, as one appreciates a work of fine art, music or literature (poetry, prose, language, philosophy). Albert Einstein observed that: "The most beautiful thing we can experience is the mysterious. It is the source of all true art and science. ${ }^{156}$

However, it seems that the greatest dimension to art as a human attribute is the capacity to imagine things. This capability is not in any way scientific, since imagination is a type as well as an aspect of speculation, and the boundary of the scientific method ends abruptly with experimentation. The materials which science experiments on are not assembled by science: it has no such tools, for hypotheses are products of artistic speculation, or, more specifically, imagination of hypothetical reality.

Given that art is imagination, it is worthwhile to point out that art is also responsible for expression of the imagination. Art provides means to express the imagination both in language and in non-grammatical ways that are not tied to the formality of spoken or written language. Unlike words, which come in sequences and each of which have a definite meaning, fine art and instrumental music provide a 
range of forms, symbols and ideas with meanings that are malleable. According to Immanuel Kant:

Jupiter's eagle [as an example of art] is not, like logical (aesthetic) attributes of an object, the concept of the sublimity and majesty of creation, but rather something else - something that gives the imagination an incentive to spread its flight over a whole host of kindred representations that provoke more thought than admits of expression in a concept determined by words. They furnish an aesthetic idea, which serves the above rational idea as a substitute for logical presentation, but with the proper function, however, of animating the mind by opening out for it a prospect into a field of kindred representations stretching beyond its ken. ${ }^{57}$

Art is also responsible for universal communication. Art allows the individual to express things toward the world as a whole. The entire gamut of oral and written communication belongs to art. Communication is intrinsically artistic. To imagine a world without communication is to imagine a world without existence, for existence without communication becomes impossible. The integral nature of art to the human being re-echoes here.

\section{Motivated Functions of Art}

Motivated purposes of art refer to intentional, conscious actions on the part of the artists or creator. These may be to bring about political change, to comment on an aspect of society, to convey a specific emotion or mood, to address personal psychology, to illustrate another discipline, to (with 
commercial arts) sell a product, or simply as a form of communication.

\section{Art and Political Unity/Nationalism}

Art, including visual arts, music and literature, is instrumental to forging national unity and political solidarity. When we remember national flags, national anthem, national coat of arms, national monuments, national uniforms, we see that these are works of art which have been calculated to produce loyalty and allegiance. They make members of the same nation or organization to have a feeling of oneness and common bond. The constitution is a piece of literature whose grave consequences reach far beyond the relatively small size of the publication. At the beginning of this constitution is usually the overall guiding philosophy of the nation. In this way we see the role of art in making a nation. Thus nationalism often begins on the literal and symbolic level: the individual is to be surrounded by arts and symbols which speak to him the message of merging with others to become a single political entity.

Also, one of the defining functions of early twentieth century fine art has been to use visual images to bring about political change. Art movements that had this goalDadaism, Surrealism, Russian Constructivism, and Abstract Expressionism, among others-are collectively referred to as the avant-garde arts.

\section{Art as a Form of Religious and Ritual Expression}

Most of the world's religions are linked to all forms of art, involving the fine, performance and literary arts. Every religion, with an arguable exception of Islam in the area of paintings, pictures and sculptures ${ }^{58}$, can refer to some arts works and texts as well as music. For instance, Rachel Campbell-Johnston traces the relationship between art and 
Christianity to the catacombs of the early church. ${ }^{59}$ Since then, the church has always used art and literature to facilitate worship and also to propagate the faith. This is seen in the various vestments which are worn during church service, and also the depiction of God, Jesus Christ, the Blessed Virgin Mary, the saints, and certain venerable individuals. Also of prime importance are objects like the crucifix and other Christian religious objects. As a piece of verbal art, the Bible is arguably the most venerated literature in the world. Even the way Christian churches are built and the designs with which these are built are often meant to be works of art which convey certain messages to the observer. A dimension of this fact is that some churches in certain parts of the world with decreased membership or faithful have been turned into museums. For centuries the Church was the main patron of art. Art galleries are often termed the cathedrals of art, but it's the real, great cathedrals of Europe that testify not only to man's highest spiritual aspirations but to his loftiest cultural ambitions. The training given to religious leaders, in a way, has artistic significance, because it is geared to convey through their character to the congregation a picture of focusing on the main religious objective, which is uniting with God.

The above means that art serves ritualistic and symbolic functions. There can be no ceremony or ritual which does not contain art. In many cultures, art is used in rituals, performances and dances as a decoration or symbol. While these often have no specific utilitarian (motivated) purpose, anthropologists know that they often serve a purpose at the level of meaning within a particular culture. This meaning is not furnished by any one individual, but is often the result of many generations of change, and of a cosmological relationship within the culture. 


\section{Art as a Form of Ethical Prescription}

Art has been linked to ethics and morality. We can say that most of the world's moral principles are documented in literature. The Christian Bible, Islamic Quran, the constitution of countries and organizations, the manual of conduct of groups, are all verbal artistic representations of how to behave in a certain context and environment. Not only this, certain music including Christian music does the work of reminding us about the profitability of doing good and the futility of bad acts. To promote moral standard, certain works of art like pictures of nude people are discouraged. Literature also serves to change moral perspectives and views and look at moral issue in a new way. According to Peter Lamarque:

It is not the central task of ethics to formulate and apply general principles but rather to stress the particularity of moral situations and the idea that profound moral disagreements reside not in a difference of beliefs but in different ways of looking at the world. The argument is then brought to bear on literature with a parallel more or less explicitly drawn between a moral agent on the one hand and a competent reader on the other. The idea is that the moral agent and the reader both in effect confront complex moral situations with both called upon to adopt an imaginative perspective on those situations which should yield in the one case a moral judgement or appropriate action and in the other a moral insight or revised way of seeing. A competent reader might hope to learn from the literary work not by formulating a derived moral principle but by acquiring a new vision or perspective on the world. ${ }^{60}$ 
The above passage shows how art, literature in particular, can be used to show a new perspective to certain old moral norms. Secondly, verbal art is used to preserve certain moral teachings against adulterations, because once they have been written, they cannot be changed.

\section{Art for Psychological and Healing Purposes}

Art is also used by art therapists, psychotherapists and clinical psychologists as art therapy. The Diagnostic Drawing Series, for example, is used to determine the personality and emotional functioning of a patient. The end product is not the principal goal in this case, but rather a process of healing, through creative acts, is sought. The resultant piece of artwork may also offer insight into the troubles experienced by the subject and may suggest suitable approaches to be used in more conventional forms of psychiatric therapy. ${ }^{61}$

\section{Art for Social Inquiry and Criticism}

While similar to art for political change, critical art may seek to question aspects of society. In this case, the function of art may be simply to criticize some aspect of society. This is achieved through all the forms of art: visual (paintings and sculpture), performed (drama) and literature (philosophy). Philosophy, which is a critical disciple, is a veritable tool for re-evaluating systems and thoughts in any era and situation without appeal to any authority. Satirical plays have often been used to teach some erring despots lessons which they refused to learn through other channels. The distinguishing feature of artistic criticism here (especially fine art and drama) is that it often becomes the only way, (albeit an 
indirect one) to criticize a status quo when tyranny has quashed all other freedoms of expression.

\section{The Role of Art in Social Integration}

There are at least three different ways of understanding the concept of social integration. For some, it is the situation in society where everybody can aspire to the same type of goal, implying equal opportunities and rights for all human beings. In this case, becoming more integrated implies improving life chances. To others, integration has a negative connotation of an unwanted imposition of uniformity. And, to still others, the term does not necessarily imply either a positive or a negative state. It is simply a way of describing the established patterns of human relations in any given society. In this study, we tend to agree with the first view. Thus we see social integration as a process of bringing together society into a coherent whole where everybody can reach out as high as he or she wants in his or her aspirations without the barriers and biases of present society. And we see that art can play a crucial role in this in facilitating the maximum exposure of the individual to social, economic, political and career consciousness through the electronic and print media among other means. These avenues already serve as some substantial form of education and enlightenment, quite apart from formal education.

\section{Art as a Tool of Social Engineering}

Art can aid in speeding up the process of social cohesion. According to Denis Dutton (1991), one of the prime universals of arts is that it helps to shape up individual and society behaviour. This is done by picking up crucial societal problems, putting them into drama, prose, poem or philosophy in order to distinguish and emphasize their significances and consequences in a bid to get people better 
informed, or at least stimulate deeper meditations on issues that would otherwise have been generally overlooked or taken for granted in daily life. In this way, art is crucial to social engineering as it can help to influence individual and society behaviour towards a particular goal. Thus, it is a veritable tool of social engineering.

\section{Art and African Economy, Enhancing Our Standard of Living}

Even though art is originally meant to provide non-utilitarian pleasure (people generally enjoy art for art's sake, and don't demand that it keep them warm or put food on the table), it is often a serious form of income. On the individual level, it can make an artistic genius rich; on the national level, it is a good income earner for some countries through tourist attractions which are works of art. In Nigeria, for example, the Olumo rock, the Jos plateau, the Terra Cotta heads of Abeokuta, the Bauchi mountain stones, the recently constructed Tinnapa resort in Calabar, etc, have attracted foreign tourists with resultant improved foreign exchange for the country. With a sincere and dedicated government, this income, along with others, is capable of reflecting on the economy and lives of the citizens. This makes art a good source of economic income both at individual and societal levels.

Writing on arts learning and the creative economy, Jack Yantis points out that the integrated arts educator recognizes that creativity is essential to the way we live and work today and contemplates how professional development will be reformed to discover new ways to foster creativity while providing a structure in which to produce and manage work. ${ }^{62}$ Yantis recognizes that creativity, which is artistic, is indispensable to daily life. 


\section{Art and Education Enhancement}

It is a well known fact that education depends so much on art to make it effective. At the nursery educational level, children learn faster when they read textbooks filled with colourful artistic illustrations. This makes it easier for them to relate what they are learning with familiar objects they have been seeing. Children textbooks can contain drawings and pictures of human beings, house-hold and domestic appliances, vehicles and bikes, ships and planes. At such level, even mathematics text books will likely contain pictures of stones and other countable objects which are meant to be summed up or separated in order to acquire the idea of addition and subtraction. Thus, the first mathematical capability of a normal human being is likely to begin with counting physical objects, but more likely in our era, artistic illustrations. At primary, both most especially, secondary and tertiary educational levels, mathematical, algebraic, physical, or chemical and other scientific keys to complex problems are usually represented in short artistic formulae which sidetrack very long sentences and chains of mathematical deductions. Geographical and geological sciences rely heavily on maps and diagrams, which are artistic representations of places, topography and soil types. In general, we can say that art forms one of the major pillars of education, both formal and informal. Recognizing the importance of art in education, Dee Dickinson wrote that:

Always among the highest expression of every culture, the arts teach us much about every historical period through its literature, visual arts, music, dance, and drama. Today it is recognized that to be truly well educated one must not only learn to appreciate the arts, but must have rich opportunities to actively 
participate in creative work. The arts are languages that most people speak, cutting through individual differences in culture, educational background, and ability. They can bring every subject to life and turn abstractions into concrete reality. Learning through the arts often results in greater academic achievement and higher test scores. ${ }^{63}$

On the educational dimension of performance art, Richard Lewis writes that "... play is the great discoverer, and its discoveries are the frontiers and landscapes of our imagining mind. While our hands play, the inner realms of our imagination grow. We literally learn to see through playing and imagining, a world not only in front of us, but a deeper world suggested by the dance of our imagining self.",64

According to Stephanie B. Perrin, the view of intensive arts as impractical and elitist is mistaken. On the contrary, arts education can prepare students for life and work by developing in them the general skills and attitudes, the habits of heart and mind they need to prevail in postmodern society no matter what career they chose. In this regard, Perrin observes that art provides students with a more flexible, imaginative, initiative and innovative posture to life. $^{65}$

\section{Art and the Question of Dispensability: A Philosophical Evaluation}

Philosophy is concerned with study of things in their first principles and ultimate reality. It tries to answer ultimate questions about things. It also investigates the foundation of things and foundational issues to know if the said things are justified, or whether they are based on the right foundations. While other disciplines especially the scientific disciplines 
attempt to ask as well as answer the 'how' of things, philosophy asks and tries to answer the question of the 'why' of things. This enables philosophy to get at the root of things and tackle questions on why they should even exist. In this connection, the issue of the dispensability of art is in need of philosophical evaluation. Central to this is the question of the very justification of art. Somebody may ask whether art is justified as an aspect of man's life, especially since it is not originally meant to have much practical value. Philosophically seen, art is one of the ways by which man's life is made much easier and tolerable. Philosophical insight, which is a product of art, can elevate the mind to a more transcendental and ultimate disquisition of the meaning and end of life in general, and thus confer more meaning and purpose to the otherwise painful and disjointed vicissitudes of life. The site of artistically beautiful things and lovely sounds which caress the senses can go a long way to prevent tensions of the mind, stress, fatigue, high blood pressure, hypertension, uneasiness, and so on. These human problems are universal, and the prime question is not whether they can be eradicated, but how to minimize them. Philosophy sees these problems as inevitable, but equally sees that they can be kept minimum, ineffectual and incapable of overcoming the mind, through, for instance, aesthetics and the appreciation of art in all its forms. Thus, art is very crucial, very often even more crucial when compared to many of the things which are commonly regarded as having practical value. Art has a transformative capacity: it confers particularly appealing or aesthetically satisfying structures or forms upon a set of originally unrelated and passive constituents. Art confers a sentient value quite apart from its practical or utilitarian value which is equally noteworthy when it has one.

The second philosophical question that may be asked is whether there is an objective way to decide that something 
is beautiful and artistic. The appellation 'beauty' here is not restricted to visual arts. We can call a person, a house, a symphony, a fragrance, and a mathematical proof beautiful. What characteristics do they share which give them that status? What possible feature could a proof and a fragrance both share in virtue of which they both count as beautiful? Wittgenstein argued in his lectures on aesthetics that there could be some underlying unity to aesthetic judgment and hence some way to articulate the similarities of a beautiful house, beautiful proof, and beautiful sunset, except perhaps that defining it requires a description of the entire phenomenon. On the common level, however, it is clear that we are tended to describe certain persons, houses, academic renditions, or music performances as beautiful. Kant the philosopher had noted that beauty is objective and universal; thus certain things are beautiful to everyone. ${ }^{66}$ Despite this, however, there is a saying that beauty is in the eye of the beholder. Considering in part the adage just quoted, Kant's statement is correct to some extent but not completely: there are certain things that are clearly beautiful to everyone, but some others will depend on the individual observer, reader or listener. This means that the appreciation of art can be both subjective and objective. Kant merely referred to certain obvious instances of beauty which transcend subjectivity. With regard to less obvious instances, however, somebody can see something and appreciate it as work of art while the next person will not.

This raises the question of whether art means that something is beautiful, or, specifically, whether beauty can be taken as the central objective of art. Historically, modern and renaissance art scholars saw beauty as central to art and beauty as the main project and meaning of art. For Baumgarten, for instance, aesthetics is the science of the sense experiences, a younger sister of logic, and beauty is 
thus the most perfect kind of knowledge that sense experience can have. ${ }^{67}$ For Schiller (1984: 26) aesthetic appreciation of beauty is the most perfect reconciliation of the sensual and rational parts of human nature. ${ }^{68}$

However, in the twentieth century, post-modern scholars argued against the paradigm of beauty as the main paradigm of art. Croce suggested that "expression" should be the central concern of art that is, art should have the primary aim of trying to express something the artist feels or thinks. ${ }^{69}$ This is called 'expressionism' in the philosophy of art, a movement which sought to present the world under an utterly subjective perspective, violently distorting it to obtain an emotional effect and vividly transmit personal moods and ideas. ${ }^{70}$ George Dickie suggested that art derives its meaning from the sociological institutions of the art world. ${ }^{71}$ Marshall McLuhan suggested that art always functions as a "counterenvironment" designed to make visible what is usually invisible about a society. ${ }^{72}$ Theodor Adorno felt that the meaning of art is often imposed on it by the culture industry. ${ }^{73}$ Arthur Danto has described this reaction as "kalliphobia" or phobia for beauty (after the Greek word for beauty - 'kalos'). ${ }^{74}$ In this study, we used both the modern and post-modern view of art, because when we talk about art as tourist attraction, we are referring to art that is beautiful enough to attract people from all over the world; but when we talk about art in education, like literature (philosophy and linguistics) and the art objects used in mathematics and sciences, their relevance in such areas is not primarily that of beauty. So art can be used both for beautiful and nonbeautiful purposes. In this way we can reconcile the modern and post-modern conflict on the We meaning of art.

Having earlier seen that art is very instrumental to social integration, cohesion and engineering. The central point is that society cannot do without arts. Contrary to what 
some people may think, it is not possible to imagine existence without art, because even the movement of the body is artistic and stylishly done. Every element of life contains an instance of art. Art is no less important in any way than is science to human existence in general. It is crucial to recommend art as compulsory not only at the nursery, primary and secondary levels, but at the tertiary level. This is because the study of art helps flexibility of mentality and the capacity to be more imaginative in approaching problems. The very spectre of imagination makes art completely indispensable in human affairs. The scientist stands in greatest need of art, for his scientific inventions must emerge from the quality of the mind's contemplation of an imagined society which is being idealized or made more comfortable on the theoretical level by a particular imagined technology or formula. Such imagined situation, which is hypothetical, serves as the initiator and prelude to different hypotheses which undergo scientific tests in search of a theory or finding that precedes invention. The act of imagination at this crucial first stage of the graphic picturing of hypothetical reality is not a scientific exercise (as science is restricted to experimentation and has nothing to do with the imagination), it is artistic, and every dimension of art (visual, verbal, speculative) is involved in this determining process. This means that the acquisition of any form of knowledge must begin with the artistic method, the speculative or picturing method. Other methods of knowledge acquisition including the scientific method can proceed with the results of speculation or/and imagination.

\section{Conclusion}

From what we have done it is clear that art cannot be overlooked in the society. It is integral to the human being, fosters political unity, it helps religious devotion, helps in moral teaching, is crucial to education, earns income both 
individually and nationally, and is indispensable to science. All these apply to society. Since art is so integral to man, it is therefore indispensable.

\section{References}

Gombrich, Ernst. (2005). "Press statement on The Story of Art". The Gombrich Archive. http://www.gombrich.co.uk/showdoc.php?id=68. Retrieved 2008-11-18.

2 Britannica Online, www.britannicaonline Retrieved 2010/04/23

${ }^{3}$ Elkins, James "Art History and Images That Are Not Art", The Art Bulletin, Vol. 47, No. 4 (Dec. 1995), with previous bibliography. "Non-Western images are not well described in terms of art, and neither are medieval paintings that were made in the absence of humanist ideas of artistic value". p. 553. Since philosophy is also an art, we recall Levy-Bruhl's denial of the capacity of Africans for elementary logic.

${ }^{4}$ Richard Wollheim, Art and Its Objects, 2nd edn, 1980, Cambridge University Press, p.1.

${ }^{5}$ Leo Tolstoy, quoted in Richard Wollheim, Art and Its Objects, p. 1.

${ }^{6}$ Benedetto Croce and R.G. Collingwood's views, expressed in The Principles of Art, is considered in Wollheim, Op. Cit. 1980 pp 36-43.

${ }^{7}$ Martin Heidegger, "The Origin of the Work of Art", in Poetry, Language, Thought, Harper Perenniel, 2001. See also Maurice Merleau-Ponty, "Cézanne's Doubt" in The MerleauPonty Aesthetics Reader, Galen Johnson and Michael Smith (eds), (Northwestern University Press, 1994) and John 
Russon, Bearing Witness to Epiphany, New York: State University of New York Press, 2009.

${ }^{8}$ Radford, Tim, "World's Oldest Jewellery Found in Cave", Guardian Unlimited, April 16, 2004. Retrieved on January 18, 2008.

9 Art, From Wikipedia, the free encyclopedia, http://en.wikipedia.org/wiki/Art Retrieved 2010/04/23

${ }^{10}$ Steve Mithen, The Prehistory of the Mind: The Cognitive Origins of Art, Religion and Science, New York: MacGrawHill, 1999, p. 72.

${ }^{11}$ Francis Frascina and Charles Harrison (eds.), Modern Art and Modernism: A Critical Anthology, New York: BobbsMerril, 1982, p 8.

12 Wilford, John N., "Flutes Offer Clues to Stone-Age Music", The New York Times, June 24, 2009, doi:10.1038/nature07995.

${ }^{13}$ Genesis 4:21, The Bible (RSV).

${ }^{14}$ Genesis 31:27, The Bible (RSV).

${ }^{15}$ Exodus 15, The Bible (RSV).

${ }^{16} 2$ Samuel 19:35; Ecclesiastes 2:8, The Bible (RSV).

172 Samuel 6:5; 1st Chronicles 15:16; 23;5; 25:1-6, The Bible (RSV).

${ }^{18}$ Ecclesiastes 2:8; Amos 6:4-6; Isaiah 5:11, 12; 24:8, 9; Ps. 137; Jeremiah 48:33; Luke 15:25, The Bible (RSV). See also Easton's Bible Dictionary, "Music", 1897.

19 "A Theatre Before the World: Performance History at the Intersection of Hebrew, Greek, and Roman Religious Processional," The Journal of Religion and Theatre, Vol. 5, No. 1, Summer 2006.

${ }^{20}$ Ibid.

${ }^{21}$ Kilmer, Crocker, Brown, Sounds from Silence, 1976, Bit Enki, Berkeley, Calif., LCC 76-16729.

${ }^{22}$ Aristotle, Problems, Book XIX.12. 
23 Reginald and Jamila Massey, The Music of India, http://en.wikipedia.org/wiki/History_of_classical_music_trad itions

24 History of Classical Music Traditions, From Wikipedia, the free encyclopedia, http://en.wikipedia.org/wiki/History_of_classical_music_trad itions Retrieved 2010/04/23

25 Richard H. Hoppin, Medieval Music, New York, W.W. Norton \& Co., 1978, p. 26-42.

${ }^{26}$ Gustave Reese, Music in the Renaissance, New York, W.W. Norton \& Co., 1954, p. 55.

27 Merker, Brown, Steven (eds.), The Origins of Music, The MIT Press, 2000, pp. 553-559.

28 Ibid., p. 558.

29 Charles Kahn, World History: Societies of the Past, London, Frank Cass, p. 98.

30 Nidel Nidel and Richard O. Nidel, World Music: The Basics, London: Cranston, 2010, p. 219.

31 Elliot Schwartz and Daniel Godfrey, Music Since 1945, New York: Simon \& Schuster Macmillan, 1993, pp 61-75.

32 History of Literature, From Wikipedia, the free encyclopedia,

http://en.wikipedia.org/wiki/History_of_literature Retrieved 2010/04/23

33 Ibid.

34 Ibid.

35 In portraying the two cities and their characteristics, Augustine, City of God set the pace for Christian literary teaching in the use of literary style to offer insight into religious issues. Cf Augustine, City of 
God, trans by Bettenson, H., London: Penguin Classics, 1972.

36 Cf: Augustine, The Confessions, trans by Borruso S., Nairobi: Pauline's Publication, 2003.

${ }^{37}$ Irwin, Robert, The Arabian Nights: A Companion, London: Tauris Parke Paperbacks, 2003, p. 209.

38 Achmed A. W. Khammas, Science Fiction in Arabic Literature, Turrin: Messackmack, 1996, p. 2.

39 Matthew Richardson, The Halstead Treasury of Ancient Science Fiction, Rushcutters Bay, New South Wales: Halstead Press, 2001, p. 5.

${ }^{40}$ Ibid., pp. 6-7.

${ }^{41}$ Ibid., p. 8.

42 "Romantic Literature", in Romanticism, From Wikipedia, the free encyclopedia, http://en.wikipedia.org/wiki/Romanticism Retrieved 2010/04/23

43 R.E. Allen, Plato: The Republic. New Haven: Yale University Press, 2006, VII.6-VII.18. 521c-541b.

${ }^{44}$ Ernest Albee, The Meaning of Literature for Philosophy, International Journal of Ethics 20:1 (1909), pp. 1-10.

${ }^{45}$ Wayne C. Booth, "Why Banning Ethical Criticism is a Serious Mistake", Philosophy and Literature 22: 2 (1998), pp. 55-58.

${ }^{46}$ Ibid. 
47 History of Literature, From Wikipedia, the free encyclopedia,

http://en.wikipedia.org/wiki/History_of_literature Retrieved 2010/04/23

48 Abu Shadi Al-Roubi, "Ibn Al-Nafis as a philosopher", Symposium on Ibn al-Nafis, Second International Conference on Islamic Medicine: Islamic Medical Organization, Kuwait, 1982 (cf. Ibn al-Nafis As a Philosopher, Encyclopedia of Islamic World).

49 Bryan Magee, The Philosophy of Schopenhauer, Oxford: Oxford University Press, revised edition, 1977, p. 77.

50 Jorge Luis Borges, Collected Fictions, translated by Andrew Hurley, London: Frank Cass, 1998, p. 4.

51 Ifechukwu J. Ndianefoo, "Between the African and the Western Mind: Philosophical Parallels in Things Fall Apart", UJAH: UNIZIK Journal of Arts and Humanities, 10: 1 (2009), p. 1.

52 Ibid., p. 2.

53 Aesthetics, From Wikipedia, the free encyclopedia, http://en.wikipedia.org/wiki/Aesthetics Retrieved 2010/04/23 54 The Hitchhiker's Guide to the Galaxy, by Douglas Adams, http://en.wikipedia.org/wiki/Aesthetics Retrieved 2010/04/23 55

Aristotle.

The

Poetics,

Republic, http://www.authorama.com/the-poetics-2.html Retrieved 2010/04/23

56 Einstein, Albert. The World as I See It. http://www.aip.org/history/einstein/essay.htm Retrieved 2010/04/23

57 Immanuel Kant, Critique of Judgment, translated by Werner S. Pluhar, London: Hackett Publishing Co., 1790 (1987), p. 17.

58 According to Islam, human works of art are inherently flawed compared to the work of God; thus, it is believed by 
many that to attempt to depict in a realistic form any animal or person is insolence to God. Human or animal depiction is generally forbidden altogether in Islamic cultures. Human portrayals can be found in early Islamic cultures with varying degrees of acceptance by religious authorities. Human representation for the purpose of worship that is uniformly considered idolatry as forbidden in Sharia law. Cf: Penelope J.E Davies et. al., History of Art, Seventh Edition, New Jersey: Prentice Hall; 2007, p. 277. 59

Rachel

Campbell-Johnston, http://entertainment.timesonline.co.uk/tol/arts_and_entertain ment/visual_arts/article7084421.ece Retrieved 2010/04/23 60 Peter Lamarque quoted in Jeffrey Dean, Aesthetics and Ethics: The State of the Art, http://www.aestheticsonline.org/articles/index.php?articles_id=15 Retrieved 2010/04/23

61 Art Therapy, From Wikipedia, the free encyclopedia, http://en.wikipedia.org/wiki/Art_therapy\#The_Diagnostic_Dr awing_Series_.28DDS.29 May 19, 2010

62 Jack Yantis, (2010) , Art in Education, http://www.newhorizons.org/strategies/arts/front_arts.htm, Retrieved 2010-04-23.

63

Dee Dickinson, Art in Education, http://www.newhorizons.org/strategies/arts/front_arts.htm, Retrieved 2010-04-23.

64 Richard Lewis, Art in Education, http://www.newhorizons.org/strategies/arts/front_arts.htm, Retrieved 2010-04-23.

65 Stephanie B. Perrin, Art in Education, http://www.newhorizons.org/strategies/arts/front_arts.htm, Retrieved 2010-04-23. 
66 Immanuel Kant, Critique of Judgment, translated by Werner S. Pluhar, London: Hackett Publishing Co., (1790)1987, p. 79.

${ }^{67}$ Baumgarten, quoted in Leo Tolstoy, What is Art? London: Penguin Books, 1995, III.

${ }^{68}$ Schiller, On the Aesthetic Education of Man, ed. Wilinson and Willoughby, 1967 (OED) cited in Friedrich Schiller (From Wikipedia, the free encyclopedia, http://en.wikipedia.org/wiki/Friedrich_Schiller_Retreived 2010/05/03

${ }^{69}$ Benedetto Croce, Aesthetic as Science of Expression and General Linguistic, (1909; 2nd ed., New York: PD, 1922, P. 4.

70 Confer Bruce Thompson, Lecture On Weimar Culture/Kafka's Prague, Santa Cruz: University of California Press, 2007. See also Chris Baldick, Concise Oxford Dictionary of Literary Terms, entry for Expressionism.

71 George Dickie, Art and the Aesthetic: An Institutional Analysis, New York: Cornell University Press, 1974, p. 24.

72 Marshall McLuhan, The Medium is the Massage: An Inventory of Effects with Quentin Fiore, produced by Jerome Agel; 1st Ed.: Random House, 1967; reissued by Gingko Press, 2001, p. 2.

73 Theodor Adorno, Aesthetic Theory, Minneapolis: University of Minnesota Press, 1996, p. 47.

74 Arthur Danto, 'Kalliphobia in Contemporary Art', Art Journal 63: 2 (2004) pp. 24-35.

*Dr. Emmanuel Ifeanyi Ani is of the Department of Philosophy and Classics, University of Ghana, Accra-Legon. 